\title{
Genes Involved in the Enamel Development Are Associated with Calcium and Phosphorus Level in Saliva
}

\author{
Erika Calvano Küchler ${ }^{a}$ Giovana Daniela Pecharki $^{d}$ Myrella Lescio Castro $^{b}$ \\ Junia Ramos $^{\text {b }}$ Fernando Barbosa Jr. $^{c}$ João Armando Brancher ${ }^{\mathrm{e}}$ \\ Alexandre Rezende Vieira ${ }^{g}$ Raquel Fernanda Gerlach ${ }^{b}$ Paula Cristina Trevilatto ${ }^{f}$ \\ Departments of a Pediatric Dentistry and ${ }^{\mathrm{b}}$ Morphology, Physiology and Basic Pathology, Ribeirao Preto Dental \\ School, and ' Department of Clinical, Toxicological and Bromatological Analysis, Faculty of Pharmacy of Ribeirao \\ Preto, USP - University of Sao Paulo, Ribeirao Preto, and ${ }^{\mathrm{d}}$ Department of Community Health, Federal University of \\ Parana, ${ }^{e}$ Department of Dentistry, Universidade Positivo, and ${ }^{f}$ Center for Health and Biological Sciences, Pontifícia \\ Universidade Católica do Paraná (PUCPR), Curitiba, Brazil; ${ }^{9}$ Department of Oral Biology, University of Pittsburgh, \\ Pittsburgh, Pa., USA
}

\section{Keywords}

Enamel · Polymorphism · Saliva

\begin{abstract}
Saliva components play a crucial role in the integrity of the dental enamel and in caries susceptibility. The saliva characteristics are controlled by many factors, including genetic factors. Therefore, this study aimed to evaluate the association between the genetic variations in genes expressed in enamel development with calcium and phosphorus levels in saliva. We collected 276 unrelated 12-year-old children from private and public schools. Saliva was collected for DNA extraction from oral cells and for measurement of calcium and phosphorus. Inductively coupled plasma-mass spectrometry determined calcium and phosphorus levels in whole saliva. Fifteen genetic variations in 9 genes were analyzed. The genotype was determined by real-time polymerase chain reactions. Data were analyzed using Plink with an alpha of $5 \%$. Genetic variations in AMELX, AMNB and ESRRB were associated with the calcium level in saliva $(p<0.05)$. A borderline
\end{abstract}

\section{KARGER}

(C) 2017 S. Karger AG, Basel

E-Mail karger@karger.com

www.karger.com/cre association was observed in ENAM allele distribution shown with phosphate level in saliva $(p=0.049)$. In conclusion, our results are the first to report that genetic variations contribute to calcium and phosphorus levels in saliva.

(c) 2017 S. Karger AG, Basel

Dental enamel is the hardest substance in the human body and contains the highest percentage of minerals. The mineralization of the dental enamel is a complex process involving the sequential passage of mineral ions across cell and fluid barriers, in which several key genes are involved in the enamel formation stages, mediated by the ameloblasts [Lacruz et al., 2012].

It is well known that, in the oral cavity, a high concentration of calcium phosphate salts is dissolved in saliva [Burstein et al., 1979]. The saliva components play a crucial role in the integrity of the dental enamel as well as in caries susceptibility, since saliva needs to be supersaturated in relation to calcium and phosphate, otherwise enamel apatite will dissolve. Thus, saliva helps in the

Paula Cristina Trevilatto

Center for Health and Biological Sciences

Pontifícia Universidade Católica do Paraná (PUCPR)

Rua Imaculada Conceição, 1155, Curitiba, PR 80215-901 (Brazil)

E-Mail paula.trevilatto@pucpr.br 
enamel stability and protection [Hay et al., 1986; Larsen and Pearce, 2003].

Calcium and phosphate levels in saliva are controlled by many factors, including host factors. Genes involved in the enamel development are candidates for altered levels of calcium and phosphorus in saliva. Therefore, the present study aimed to evaluate genetic variations in genes expressed in enamel development and their association with calcium and phosphorus levels in saliva.

\section{Methods}

\section{Studied Population and Clinical Examination}

The Human Ethics Committee of the PUC-PR and the Pittsburgh Institutional Review Board approved this study. Informed written consent was obtained from the parents, and age-appropriate assent documents were used for all children.

Two hundred and seventy-six biological unrelated children, with no syndrome and/or systemic illness, were included. They were 12-year-old students of both sexes from private and public schools of Curitiba, P.R., Brazil. This population has previously been described [Brancher et al., 2011].

\section{Saliva Collection Measurements}

Salivary flow was evaluated by means of stimulated saliva collection. The method used was that of mechanical masticatory stimulation, using a piece of sterile rubber tourniquet of a standardized size $(1.5 \mathrm{~cm})$, masticated continuously by the patient for $6 \mathrm{~min}$. Saliva produced during the first minute of stimulation was discarded. During the following $5 \mathrm{~min}$, the patient expelled saliva into a sterilized universal collecting recipient that had been previously weighed using Marte_ analytical scales, model AL 500 (Sao Paulo, S.P., Brazil). Stimulated salivary flow rate was evaluated by means of the gravimetric method and expressed in milliliters per minute [BanderasTarabay et al., 1997]. Immediately following saliva collection, the salivary $\mathrm{pH}$ was assessed using a QUIMIS_Q400BD pocket $\mathrm{pH}$ meter (direct electrode) (QUIMIS, Diadema, S.P., Brazil).

Calcium and phosphorus levels in whole saliva were determined at the Laboratory of Metals Toxicology, University of Sao Paulo in Ribeirao Preto (Brazil), by inductively coupled plasmamass spectrometry.

The remaining saliva was used for genomic DNA extraction from buccal cells for genotyping analyses. The extraction was performed according to an established protocol [Aidar and Line, 2007].

\section{Phenotype Determination}

The phenotype determination of calcium and phosphorus was based on their values. Calcium and phosphorus were categorized as 'low' and 'high' level based on the medium value of each variable. Subjects with salivary calcium levels over the median value $(9.84 \mu \mathrm{g} / \mathrm{ml})$ were included in the 'high salivary calcium group'. Subjects with salivary phosphorus levels over the median value $(126.81 \mu \mathrm{g} / \mathrm{ml})$ were included in the 'high salivary phosphorus group'.

The caries phenotype was diagnosed using a modified World Health Organization guideline recommended for oral health sur- veys. Teeth lost to trauma or primary teeth lost to exfoliation were not included in the final DMFT scores. Carious lesions were recorded as present when a break in enamel was apparent on visual inspection. All the examiners carried out the clinical examination after being calibrated by an experienced specialist [Brancher et al., 2011]. The DMFT score ranged between 0 and 9 , and 140 children were caries free.

\section{Genotyping}

Fifteen genetic variations were selected within 9 candidate genes. The selected genes were expressed during enamel formation and/or in the salivary gland. The studied genetic variations are described in table 1 . Genotype was assessed by polymerase chain reactions (PCR) with the Taqman method with the real-time PCR system ABI PRISM ${ }^{\circledR} 7900$ HT Sequence Detection System (Foster City, Calif., USA). Probes were supplied by Applied Biosystems (Foster City, Calif., USA).

\section{Statistical Analyses}

Calcium and phosphorus values were analyzed as continuous variables and as dichotomous variables 'low' $(\mathrm{n}=138)$ and 'high' $(n=138)$. Differences in genotype and allele frequencies were tested for all phenotypes. A genotype analysis was also performed in a recessive model. The differences between 'low' and 'high' groups were tested using $\chi^{2}$ or Fisher's exact tests used with an established alpha of $5 \%$. The t test was used to compare the difference between the means. Hardy-Weinberg equilibrium was evaluated using the $\chi^{2}$ test within each single-nucleotide polymorphism.

\section{Results}

All markers studied were in Hardy-Weinberg equilibrium (data not shown). The mean calcium level was 11.34 $\mu \mathrm{g} / \mathrm{ml}( \pm 6.77$ ), while the median was 9.84 (first to third quartile, Q1-Q3), 6.77-13.65). The mean phosphate level was $133.49 \mu \mathrm{g} / \mathrm{ml}( \pm 36.94)$, while the median was 126.81 (Q1-Q3 109.32-149.47). Gender, ethnicity, age, oral hygiene habits, dietary factors and caries experience were not associated with calcium and phosphorus levels in saliva (table 2). The population characteristics and distribution between low and high calcium and phosphorus groups are presented in table 2 .

The group with low phosphorus levels had an increased salivary flow $(\mathrm{p}=0.012)$. The group with high calcium levels presented a more acid salivary $\mathrm{pH}(\mathrm{p}=$ $0.023)$. The phosphorus level exhibited a borderline association with $\mathrm{pH}(\mathrm{p}=0.056)$.

Table 3 demonstrated the genotype and the allele distribution between low and high calcium level groups. Allele distribution in AMELX was statistically different between groups $(\mathrm{p}=0.021)$. For $A M B N$, both genotype and allele distribution were statistically different between the high and low calcium groups $(\mathrm{p}=0.025$ and $\mathrm{p}<0.001)$. 
Table 1. Description of the studied genetic variations

\begin{tabular}{|c|c|c|c|c|c|c|}
\hline Gene symbol & Gene name & Variant & Location & Base change & $\begin{array}{l}\text { Average heterozygosity } \pm \\
\text { standard error }\end{array}$ & MAF \\
\hline$A M E L X$ & Amelogenin & rs946252 & $\mathrm{Xp} 22.2$ & $\mathrm{~A} / \mathrm{G}$ & $0.420 \pm 0.183$ & 0.300 \\
\hline$A M B N$ & Ameloblastin & rs4694075 & $4 \mathrm{q} 13.3$ & $\mathrm{C} / \mathrm{T}$ & $0.499 \pm 0.022$ & 0.478 \\
\hline$A Q P 1$ & Aquaporin 1 & rs17159702 & $7 \mathrm{p} 14.3$ & $\mathrm{C} / \mathrm{T}$ & $0.493 \pm 0.057$ & 0.443 \\
\hline$A Q P 8$ & Aquaporin 8 & $\mathrm{rs} 2287798^{\mathrm{a}}$ & $16 \mathrm{p} 12.1$ & $\mathrm{C} / \mathrm{G}$ & $0.485 \pm 0.085$ & 0.414 \\
\hline ENAM & Enamelin & rs12640848 & $4 q 13.3$ & A/G & $0.459 \pm 0.137$ & 0.357 \\
\hline \multirow[t]{8}{*}{$E S R R B$} & Estrogen-related receptor $\beta$ & rs745011 & $14 \mathrm{q} 24.3$ & $\mathrm{C} / \mathrm{T}$ & $0.486 \pm 0.082$ & 0.417 \\
\hline & & rs6574293 & & $\mathrm{A} / \mathrm{G}$ & $0.225 \pm 0.249$ & 0.129 \\
\hline & & rs1676303 & & $\mathrm{C} / \mathrm{T}$ & $0.326 \pm 0.238$ & 0.205 \\
\hline & & rs10132091 & & $\mathrm{C} / \mathrm{T}$ & $0.500 \pm 0.014$ & 0.486 \\
\hline & & rs2860216 & & $\mathrm{C} / \mathrm{T}$ & $0.422 \pm 0.182$ & 0.302 \\
\hline & & rs1997532 & & $\mathrm{C} / \mathrm{T}$ & $0.494 \pm 0.054$ & 0.446 \\
\hline & & rs4903399 & & $\mathrm{C} / \mathrm{T}$ & $0.293 \pm 0.246$ & 0.178 \\
\hline & & rs1077430 & & $\mathbf{A} / \mathrm{G}$ & $0.473 \pm 0.113$ & 0.384 \\
\hline TFIP11 & Tuftelin interacting protein 11 & rs5997096 & $22 \mathrm{q} 12.1$ & $\mathrm{C} / \mathrm{T}$ & $0.498 \pm 0.030$ & 0.470 \\
\hline TUFT1 & Tuftelin & rs4970957 & $1 \mathrm{q} 21.3$ & $\mathrm{~A} / \mathrm{G}$ & $0.366 \pm 0.222$ & 0.241 \\
\hline
\end{tabular}

Obtained from databases http://www.ncbi.nlm.nih.gov and http://genome.ucsc.edu. MAF = Minor allele frequency. Bold letters indicate mutant alleles.

Table 2. Characteristics of the studied subjects

\begin{tabular}{|c|c|c|c|c|c|c|}
\hline \multirow[t]{2}{*}{ Characteristics } & \multicolumn{2}{|l|}{ Calcium } & \multirow[t]{2}{*}{$\mathrm{p}$ value } & \multicolumn{2}{|l|}{ Phosphorus } & \multirow[t]{2}{*}{$\mathrm{p}$ value } \\
\hline & low $(n=138)$ & $\operatorname{high}(\mathrm{n}=138)$ & & low $(\mathrm{n}=138)$ & $\operatorname{high}(\mathrm{n}=138)$ & \\
\hline \multicolumn{7}{|l|}{ Gender } \\
\hline Male & $76(55.1)$ & $66(47.8)$ & \multirow[t]{2}{*}{$0.139^{\mathrm{a}}$} & $70(50.7)$ & $72(52.2)$ & \multirow[t]{2}{*}{$0.405^{\mathrm{a}}$} \\
\hline Female & $62(44.9)$ & $72(52.2)$ & & $68(49.3)$ & $66(47.8)$ & \\
\hline \multicolumn{7}{|l|}{ Ethnicity } \\
\hline Caucasian & $126(91.3)$ & $127(92.0)$ & \multirow[t]{2}{*}{$0.415^{\mathrm{a}}$} & $124(89.9)$ & $129(93.5)$ & \multirow[t]{2}{*}{$0.192^{\mathrm{a}}$} \\
\hline African descendents & $12(8.7)$ & $11(8.0)$ & & $14(10.1)$ & $9(6.5)$ & \\
\hline Age $\pm S D$, years & $12.0 \pm 0.48$ & $11.9 \pm 0.50$ & $0.800^{\mathrm{b}}$ & $11.9 \pm 0.53$ & $11.9 \pm 0.45$ & $0.808^{\mathrm{b}}$ \\
\hline \multicolumn{7}{|l|}{ Tooth brush frequency } \\
\hline Once a day & $73(52.9)$ & $69(51.1)$ & \multirow{2}{*}{$0.384^{\mathrm{a}}$} & $74(53.6)$ & $68(50.4)$ & \multirow{2}{*}{$0.296^{\mathrm{a}}$} \\
\hline Twice or more times a day & $65(47.1)$ & $66(48.9)$ & & $64(46.4)$ & $67(49.6)$ & \\
\hline \multicolumn{7}{|l|}{ Use of dental floss } \\
\hline No & $48(34.8)$ & $43(31.2)$ & \multirow[t]{3}{*}{$0.627^{\mathrm{a}}$} & $51(37.0)$ & $40(29.0)$ & \multirow[t]{3}{*}{$0.134^{\mathrm{a}}$} \\
\hline Sometimes & $66(47.8)$ & $74(53.6)$ & & $70(50.7)$ & $28(20.3)$ & \\
\hline Yes & $24(17.4)$ & $21(15.2)$ & & $17(12.3)$ & $70(50.7)$ & \\
\hline \multicolumn{7}{|c|}{ Ingestion of sweets between meals } \\
\hline No & $13(9.4)$ & $12(9.6)$ & \multirow[t]{2}{*}{$0.484^{\mathrm{a}}$} & $15(0.9)$ & $12(8.1)$ & \multirow[t]{2}{*}{$0.281^{\mathrm{a}}$} \\
\hline Yes & $125(90.6)$ & $126(90.4)$ & & $123(89.1)$ & $126(91.9)$ & \\
\hline $\mathrm{DMFT} / \mathrm{dmft}$ index $\pm \mathrm{SD}$ & $1.31 \pm 2.04$ & $1.50 \pm 1.77$ & $0.432^{\mathrm{b}}$ & $1.36 \pm 2.10$ & $1.45 \pm 1.70$ & $0.683^{\mathrm{b}}$ \\
\hline
\end{tabular}

Results are indicated as numbers with percentages in parentheses.

${ }^{\mathrm{a}} \chi^{2}$ test. ${ }^{\mathrm{b}} \mathrm{t}$ test. 
Table 3. Genotype and allele distribution between calcium groups

\begin{tabular}{|c|c|c|c|c|c|}
\hline \multirow[t]{2}{*}{ Gene } & \multirow[t]{2}{*}{ Variant } & \multicolumn{2}{|l|}{ Frequency } & \multirow{2}{*}{$\begin{array}{l}\mathrm{p} \text { value } \\
\text { geno- } \\
\text { type }\end{array}$} & \multirow{2}{*}{$\begin{array}{l}\mathrm{p} \text { value } \\
\text { allele }\end{array}$} \\
\hline & & $\begin{array}{l}\text { low level } \\
\mathrm{dd} / \mathrm{dD} / \mathrm{DD}^{*}\end{array}$ & $\begin{array}{l}\text { high level } \\
\mathrm{dd} / \mathrm{dD} / \mathrm{DD}^{*}\end{array}$ & & \\
\hline$A M E L X$ & rs946252 & $23 / 12 / 96$ & $31 / 21 / 82$ & 0.095 & 0.021 \\
\hline$A M B N$ & rs4694075 & $42 / 65 / 26$ & $25 / 73 / 39$ & 0.025 & $<0.001$ \\
\hline$A Q P 1$ & rs17159702 & $19 / 54 / 52$ & $13 / 57 / 43$ & 0.482 & 0.986 \\
\hline$A Q P 8$ & rs2287798 & $27 / 61 / 47$ & $27 / 52 / 55$ & 0.511 & 0.473 \\
\hline ENAM & rs12640848 & $22 / 15 / 55$ & $14 / 23 / 64$ & 0.154 & 0.214 \\
\hline \multirow[t]{8}{*}{ ESRRB } & rs745011 & $32 / 44 / 39$ & $14 / 60 / 45$ & 0.007 & 0.028 \\
\hline & rs6574293 & $4 / 24 / 100$ & $0 / 15 / 114$ & 0.030 & 0.008 \\
\hline & rs1676303 & $3 / 30 / 86$ & $2 / 25 / 83$ & 0.837 & 0.551 \\
\hline & rs10132091 & $22 / 66 / 44$ & $22 / 68 / 42$ & 0.962 & 0.944 \\
\hline & rs2860216 & $19 / 44 / 48$ & $11 / 55 / 48$ & 0.190 & 0.482 \\
\hline & rs1997532 & $6 / 28 / 36$ & $8 / 23 / 36$ & 0.701 & 0.922 \\
\hline & rs4903399 & $3 / 32 / 73$ & $9 / 36 / 72$ & 0.236 & 0.069 \\
\hline & rs1077430 & $21 / 51 / 54$ & $10 / 64 / 51$ & 0.065 & 0.438 \\
\hline TFIP11 & rs5997096 & $26 / 74 / 33$ & $24 / 75 / 36$ & 0.903 & 0.398 \\
\hline TUFT1 & rs4970957 & 2/53/74 & $5 / 42 / 82$ & 0.226 & 0.307 \\
\hline
\end{tabular}

* Uppercase letters denote the wild-type allele. Bold figures indicate statistically significant differences.

Two polymorphisms in ESRRB (rs745011 and rs6574293) were also associated with calcium level (table 3). Also, in a recessive model, the polymorphism rs 1077430 in ESRRB analysis demonstrated that the AA genotype was associated with low calcium level $(\mathrm{OR}=2.3$, $95 \% \mathrm{CI}=1.1-5.1 ; \mathrm{p}=0.036)$.

Table 4 demonstrates the genotype and the allele distribution between low and high phosphorus level. Phosphorus level was associated only with the allele distribution of the genetic variant in ENAM ( $\mathrm{p}=0.049)$.

\section{Discussion}

Intraoral mineralization capacity has been a matter of scientific interest for decades. To the best of our knowledge, this is the first study that aimed to evaluate the role of the genetic background in the calcium and phosphorus levels in saliva. We evaluated genes involved in enamel development due to the relationship that exists between the dental enamel and these components in saliva and caries susceptibility. To understand their relationship, it is important to know that the mature dental enamel is a crystalline structure containing up to $96 \%$ hydroxyapatite $\left[\mathrm{Ca}_{10}\left(\mathrm{PO}_{4}\right)_{6}(\mathrm{OH})_{2}\right]$ by weight and with water and protein accounting for the other $4 \%$ [Mann and Dickinson, 2006].
Table 4. Genotype and allele distribution between phosphorus groups

\begin{tabular}{|c|c|c|c|c|c|}
\hline \multirow[t]{2}{*}{ Gene } & \multirow[t]{2}{*}{ Variant } & \multicolumn{2}{|l|}{ Frequency } & \multirow{2}{*}{$\begin{array}{l}\mathrm{p} \text { value } \\
\text { geno- } \\
\text { type }\end{array}$} & \multirow{2}{*}{$\begin{array}{l}\mathrm{p} \text { value } \\
\text { allele }\end{array}$} \\
\hline & & $\begin{array}{l}\text { low level } \\
\mathrm{dd} / \mathrm{dD} / \mathrm{DD}^{*}\end{array}$ & $\begin{array}{l}\text { high level } \\
\mathrm{dd} / \mathrm{dD} / \mathrm{DD}^{*}\end{array}$ & & \\
\hline$A M E L X$ & rs946252 & $22 / 20 / 88$ & $32 / 13 / 90$ & 0.195 & 0.454 \\
\hline$A M B N$ & rs4694075 & $29 / 73 / 33$ & $36 / 65 / 34$ & 0.540 & 0.605 \\
\hline$A Q P 1$ & rs17159702 & $16 / 53 / 47$ & $16 / 58 / 48$ & 0.958 & 0.978 \\
\hline$A Q P 8$ & rs2287798 & $24 / 61 / 49$ & $30 / 52 / 53$ & 0.463 & 0.968 \\
\hline ENAM & rs12640848 & $20 / 20 / 50$ & $16 / 18 / 69$ & 0.256 & 0.049 \\
\hline \multirow[t]{8}{*}{ ESRRB } & rs745011 & $27 / 47 / 45$ & $19 / 57 / 39$ & 0.257 & 0.771 \\
\hline & rs6574293 & $2 / 19 / 106$ & $2 / 20 / 108$ & 0.995 & 0.981 \\
\hline & rs1676303 & $2 / 31 / 83$ & $3 / 24 / 86$ & 0.575 & 0.844 \\
\hline & rs10132091 & $22 / 66 / 41$ & $18 / 68 / 45$ & 0.437 & 0.277 \\
\hline & rs2860216 & $20 / 44 / 50$ & $10 / 55 / 46$ & 0.096 & 0.497 \\
\hline & rs1997532 & $7 / 24 / 40$ & $7 / 27 / 32$ & 0.642 & 0.432 \\
\hline & rs4903399 & $8 / 33 / 66$ & $4 / 35 / 79$ & 0.363 & 0.210 \\
\hline & rs1077430 & $15 / 48 / 57$ & $16 / 67 / 48$ & 0.176 & 0.163 \\
\hline TFIP11 & rs5997096 & $31 / 69 / 32$ & $19 / 80 / 37$ & 0.135 & 0.147 \\
\hline TUFT1 & rs4970957 & $1 / 47 / 80$ & $6 / 48 / 76$ & 0.159 & 0.273 \\
\hline
\end{tabular}

* Uppercase letters denote the wild-type allele. The bold figure indicates statistically significant difference.

Here, we found that genetic variations in genes involved in enamel development are associated with the calcium and phosphorus levels in saliva. Some of our previous studies investigated the association between these genes and caries susceptibility and enamel alteration [Deeley et al., 2008; Tannure et al., 2012; Shimizu et al., 2012; Jeremias et al., 2013; Abbasoğlu et al., 2015; Bayram et al., 2015]. TUFT1 and TUIP11 were associated with variations in enamel microhardness [Shimizu et al., 2012]. ENAM was associated with enamel hypoplasia [Jeremias et al., 2013]. AMELX, TFIP11, ENAM, TUFT1, $K L K 4, A M B N$ and MMP20 also showed an association between some of these genes with caries susceptibility in primary and permanent dentition [Deeley et al., 2008; Tannure et al., 2012; Shimizu et al., 2012; Jeremias et al., 2013; Abbasoğlu et al., 2015; Bayram et al., 2015].

Mature enamel contains enamel protein-specific peptides that can be recovered from mature contemporary teeth [Porto et al., 2006, 2011a], as well as from ancient teeth [Porto et al., 2011b] and fluorotic teeth [Porto et al., 2016]. Dissolution of the whole enamel allowed the identification of enamel protein-specific peptides [Castiblanco et al., 2015]. Superficial enamel etching with diluted hydrochloric acid and refinement of the recovery technique allowed the successful recovery of sex-specific peptides (dimorphic AMELX peptides) without destruction 
of the tooth crown [Stewart et al., 2016]. Peptides derived from AMELX splicing variants were also found, as well as AMBN and ENAM peptides [Stewart et al., 2016]. It is very likely that in the near future the genetic basis of enamel formation can be associated with the differences either in amino acid sequence or peptide concentration in the mature enamel.

Our results demonstrated that the calcium level was associated with genetic variations in AMELX, AMNB and ESRRB. AMELX and AMNB are involved in enamel mineralization. Mutations in both these genes are responsible for the amelogenesis imperfecta phenotype (OMIN), which supports their link with enamel alterations as well as enamel mineralization. Also, the $A M N B$ gene is located in the calcium-binding phosphoprotein gene cluster in chromosome 4.

Two genetic variations evaluated in ESRRB were associated with calcium level in saliva. Our previous work aimed to explore the role of ESRRB in the oral tissues and found an association of this gene with caries susceptibility as well as its expression in the salivary gland and in enamel development [Weber et al., 2014]. ESRRB is expressed in enamel development and could have a role in the calcium composition in the enamel. However, it is also possible that the association between ESRRB and calcium level in saliva occurs via salivary gland function. Although we demonstrated that this gene is expressed in salivary glands [Weber et al., 2014], its role in salivary function is still unknown.

ESRRB is an estrogen-related receptor gene and presents similarities with the estrogen receptor. It is likely that this gene also participates in calcium balance. Calcium is a necessary component for the maintenance of healthy teeth. Calcium as well as phosphorus concentrations in saliva and plaque plays a key role influencing the tooth demineralization and remineralization processes. This process has a strong correlation with caries experience.

It is important to emphasize that other factors might be involved in calcium and/or phosphorus levels in saliva; however, in order to minimize our bias, the sample that we used in this work did not include children with systemic illnesses. In addition the groups with low and high calcium and phosphorus levels did not present a statistical difference between caries experience and other environmental factors.

Briefly, to the best of our knowledge, this is the first study to evaluate the association between calcium and phosphate levels in saliva. More studies should be performed to evaluate the role of other genes in saliva composition as well as in oral health.

\section{Conclusion}

Genetic variations in AMELX, AMNB and ESRRB are associated with the calcium level in saliva, while genetic variation in ENAM is associated with phosphorus in saliva.

\section{Acknowledgments}

The authors are indebted to the participants of the study. Support for this work was provided by FAPESP (the State of Sao Paulo Research Foundation), CNPq (the Brazilian National Research Council) and NIH (grant: Genetics of Caries).

\section{Author Contributions}

J.A.B., P.C.T. and G.D.P. performed activities related to subject recruitment, phenotype definitions, and biological sample collection. A.R.V. and E.C.K. performed the genotyping. M.L.C., F.B., J.R. and R.F.G. evaluated the calcium and phosphate levels. A.R.V., P.C.T. and R.F.G. conceptualized and designed the study. E.C.K. analyzed and interpreted the data, and wrote the paper. All authors critically revised the manuscript.

\section{Disclosure Statement}

The authors have no conflicts of interest to declare.
References

Genetic Variants and Saliva Composition
Abbasoğlu Z, Tanboğa İ, Küchler EC, Deeley K, Weber M, Kaspar C, Korachi M, Vieira AR: Early childhood caries is associated with genetic variants in enamel formation and immune response genes. Caries Res 2015;49: 70-77.

Aidar M, Line SRP: A simple and cost-effective protocol for DNA isolation from buccal epithelial cells. Braz Dent J 2007;18:148-152.
Bayram M, Deeley K, Reis MF, Trombetta VM, Ruff TD, Sencak RC, Hummel M, Dizak PM, Washam K, Romanos HF, Lips A, Alves G, Costa MC, Granjeiro JM, Antunes LS, Küchler EC, Seymen F, Vieira AR: Genetic influences on dental enamel that impact caries differ between the primary and permanent dentitions. Eur J Oral Sci 2015, Epub ahead of print. 
Banderas-Tarabay JA, Gonzalez-Begne M, Sanchez-Garduno M, Millan-Cortez E, LopezRodriguez A, Vilchis-Velazquez A: The flow and concentration of proteins in human whole saliva. Salud Publica Mex 1997;39:433441.

Brancher JA, Pecharki GD, Doetzer AD, Medeiros KG, Cordeiro Júnior CA, Sotomaior VS, Bauer P, Trevilatto PC: Analysis of polymorphisms in the lactotransferrin gene promoter and dental caries. Int J Dent 2011;2011: 571726.

Burnstein LS, Boskey AL, Tannenbaum PJ, Posner AS, Mandel ID: The crystal chemistry of submandibular and parotid salivary gland stones. J Oral Pathol 1979;8:284-291.

Castiblanco GA, Rutishauser D, Ilag LL, Martignon S, Castellanos JE, Mejia W: Identification of proteins from human permanent erupted enamel. Eur J Oral Sci 2015;123:390395.

Deeley K, Letra A, Rose EK, Brandon CA, Resick JM, Marazita ML, Vieira AR: Possible association of amelogenin to high caries experience in a Guatemalan-Mayan population. Caries Res 2008;42:8-13.

Hay DI, Schluckebier SK, Moreno EC: Saturation of human salivary secretions with respect to calcite and inhibition of calcium carbonate precipitation by salivary constituents. Calcif Tissue Int 1986;39:151-160.
Jeremias F, Koruyucu M, Küchler EC, Bayram M, Tuna EB, Deeley K, Pierri RA, Souza JF, Fragelli CM, Paschoal MA, Gencay K, Seymen F, Caminaga RM, dos Santos-Pinto L, Vieira AR: Genes expressed in dental enamel development are associated with molar-incisor hypomineralization. Arch Oral Biol 2013;58: 1434-1442.

Lacruz RS, Smith CE, Bringas P Jr, Chen YB, Smith SM, Snead ML, Kurtz I, Hacia JG, Hubbard MJ, Paine ML: Identification of novel candidate genes involved in mineralization of dental enamel by genome-wide transcript profiling. J Cell Physiol 2012;227:2264-2275.

Larsen MJ, Pearce EI: Saturation of human saliva with respect to calcium salts. Arch Oral Biol 2003;48:317-322.

Mann A, Dickinson M: Nanomechanics, chemistry and structure at the enamel surface, in Duckworth RM (ed): The Teeth and Their Environment. Monographs in Oral Science. Basel, Karger, 2006, vol 19, pp 105-131.

Porto IM, Laure HJ, Sousa FB, Rosa JC, Gerlach RF: New techniques for the recovery of small amounts of mature enamel proteins. J Arch Sci 2011a;38:3596-3604.

Porto IM, Laure HJ, Tykot RH, de Sousa FB, Rosa JC, Gerlach RF: Recovery of mature enamel proteins in ancient teeth. Eur J Oral Sci 2011b;119:83-87.

Porto IM, Line SR, Laure HJ, Gerlach RF: Comparison of three different methods for enamel protein extraction in different developmental phases of rat lower incisors. Eur J Oral Sci 2006;114:285-286.
Porto IM, Molina GF, Souza C, Perez WB, Laure HJ, Rosa JC, Gerlach RF: Peptide characterization of mature fluorotic and control human enamel. Braz Dent J 2016;27:66-71.

Shimizu T, Ho B, Deeley K, Briseño-Ruiz J, Faraco IM Jr, Schupack BI, Brancher JA, Pecharki GD, Küchler EC, Tannure PN, Lips A, Vieira TC, Patir A, Yildirim M, Poletta FA, Mereb JC, Resick JM, Brandon CA, Orioli IM, Castilla EE, Marazita ML, Seymen F, Costa MC, Granjeiro JM, Trevilatto PC, Vieira AR: Enamel formation genes influence enamel microhardness before and after cariogenic challenge. PLoS One 2012; 7:e45022.

Stewart NA, Molina GF, Issa JPM, Yates NA, Sosovicka M, Vieira AR, Line SRP, Montgomery J, Gerlach RF: The identification of peptides by nanoLC-MS/MS from human surface tooth enamel following a simple acid etch extraction. RSC Adv 2016;66:61673-61679.

Tannure PN, Küchler EC, Lips A, Costa Mde C, Luiz RR, Granjeiro JM, Vieira AR: Genetic variation in MMP20 contributes to higher caries experience. J Dent 2012;40:381-386.

Weber ML, Hsin HY, Kalay E, Brožková DS, Shimizu T, et al: Role of estrogen related receptor beta (ESRRB) in DFN35B hearing impairment and dental decay. BMC Med Genet 2014;15:81. 